\title{
ZNACZENIE UROCZYSTOŚCI KULTOWYCH W ŻYCIU SPOŁECZNYM ARMII RZYMSKIEJ OKRESU PRYNCYPATU W ŚWIETLE FERIALE DURANUM
}

Religia zajmuje ważne miejsce $\mathrm{w}$ badaniach nad armią epoki pryncypatu począwszy już od wczesnego, przedwojennego etapu studiów poświęconych rzymskim siłom zbrojnym. Sporządzona przez Alfreda von Domaszewskiego (30 X 1856 - 25 III 1927) ${ }^{1}$ lista bóstw wchodzących w skład oficjalnego wojskowego panteonu doczekała się licznych uzupełnieńn ${ }^{2}$, a przyszłe znaleziska być może pozwolą na kolejne, zapewne szczególnie w grupie geniu$\mathrm{szy}^{3}$. W przypadku wielu prowincji dokonano ponadto zgromadzenia i analizy wszystkich, przeważnie epigraficznych, świadectw życia religijnego żołnie$\mathrm{rzy}^{4}$. Stosunkowo liczne opracowania dotyczą także niezwykle popularnego wśród żołnierzy kultu Mitry ${ }^{5}$, oraz Jowisza Dolicheńskiego ${ }^{6}$. Masowość

* Mgr Tomasz Dziurdzik - doktorant przy Zakładzie Archeologii Prowincji Rzymskich w Instytucie Archeologii na Wydziale Historycznym Uniwersytetu Warszawskiego; e-mail: tdziurdzik@wp.pl.

${ }^{1}$ Por. A. von Domaszewski, Die Religion des römischen Heeres, ,Westdeutsche Zeitschrift für Geschichte und Kunst" 14 (1895) 1-123.

${ }^{2} \mathrm{~W}$ formie kompletnej listy ostatni raz zostały zebrane w artykule E. Birley, The Religion of Roman Army: 1895-1977, ANRW II 16. 2, 1506-1541.

${ }^{3}$ Por. M.P. Speidel - A. Milčeva, The Cult of the Genii in the Roman Army and a New Military Deity, ANRW II 16. 2, 1542-1555.

${ }^{4}$ Por. prace doktorskie: J. Trynkowski, Żotnierze garnizonu rzymskiej Dacji i ich kulty, Warszawa 1968; M. Ziółkowski, Kulty religijne żolnierzy rzymskich w Brytanii w okresie wczesnego cesarstwa (I-III w. n.e.), Torun 1981/1982; w tym samym nurcie ostatnio por. O. Alexandrov, The Religion in the Roman Army in Lower Moesia Province (1st-4th c. AD), Veliko Târnovo 2010.

${ }^{5}$ Najnowsze opracowanie zagadnienia popularności tego kultu wśród żołnierzy w Europie: A. Hensen, Mithras: der Mysterienkult an Limes, Rhein und Donau, Schriften des Limesmuseums Aalen 62, Stuttgart 2013; szerzej o kulcie Mitry w świecie rzymskim: M. Clauss, The Roman Cult of Mithras: the God and his Mysteries, transl. by R. Gordon, New York 2000; R. Beck, The Religion of the Mithras Cult in the Roman Empire: Mysteries of the Unconquered Sun, Oxford - New York 2006. O powstaniu i rozwoju tego zjawiska zob. też M.P. Speidel, Mithras-Orion: Greek Hero and Roman Army God, Leiden 1980.

${ }^{6}$ Monografia związków tego kultu ze środowiskiem wojskowym: M.P. Speidel, The Religion of Juppiter Dolichenus in the Roman Army, Leiden 1978; jednym z nowszych opracowań o ogólnym charakterze jest M. Blömer, Iuppiter Dolichenus: vom Lokalkult zur Reichsreligion, Tübingen 2012; zob. też A. Collar, Military Networks and the Cult of Jupiter Dolichenus, w: Von Kummuh 
udziału wśród wyznawców zarówno szeregowych, jak i dowódców różnego szczebla, pozwala widzieć we wspomnianych kultach swego rodzaju półoficjalną religię armii rzymskiej. Po początkowym okresie badań, trwającym po lata osiemdziesiąte, charakteryzującym się perspektywą uznającą dominujące znaczenie kwestii administracyjno-formalnych w życiu żołnierzy, ostatnie dekady przyniosły poszerzenie zainteresowań badaczy o ich relacje ze sferą prywatna. Rozpatrywanych jest szereg zjawisk o bardziej indywidualnym charakterze, jak przywiązanie żołnierzy do kultów charakterystycznych dla miejsca pochodzenia, czy udział w życiu religijnym wspólnoty, wśród której przyszło im stacjonować. Wpisuje się to w popularne obecnie nurty badawcze, według których w armii rzymskiej widzieć należy nie tylko instytucję, ale także specyficzna, ściśle zdefiniowaną grupę społeczną ${ }^{7}$. Badane zjawiska i relacje nie ograniczają się jak niegdyś do oficjalnych stosunków i hierarchii, lecz uwzględniają także powiązania nieformalne, w tym również zdecydowanie ważniejsze niż niegdyś zakładano stosunki wojskowych z ludnością cywilną.

Niniejszy przyczynek jest próbą określenia znaczenia, jakie dla tak pojmowanego życia społecznego armii rzymskiej niosły oficjalne uroczystości kultowe. Wydają się one jednym z najistotniejszych czynników wpływających na tożsamość żołnierzy. Szczególnie istotną kwestią do rozważenia jest obowiązujący w wojsku kalendarz sakralny i ujęte w nim uroczystości. Ważne są nie tylko same święta, ich liczba i rozłożenie w czasie, ale także wymowa propagandowa celebrowanych okazji, stanowiąca pewnego rodzaju przekaz ideowy kierowany do żołnierzy. Wspólnota kultu i rytuałów niosła ponadto ważne implikacje, jeśli chodzi o kształtowanie wojskowych jako grupy społecznej. Stanowiła o poczuciu przynależności do zbiorowości, zarówno danego oddziału, jak i całej armii. Oficjalne uroczystości mogły mieć także niebagatelny wpływ na indywidualne postawy żołnierzy, chociażby poprzez realizację ich potrzeb, zwłaszcza religijnych oraz powiązanych z komfortem emocjonalnym i duchowym. Zbadać należy także związek zachodzący pomiędzy ceremoniami a czasem wolnym. Oficjalne uroczystości mogły dzięki niemu mieć znaczenie także dla tych spośród żołnierzy, którzy udział w nich postrzegali przede wszystkim jako obowiązek, gdyż własne potrzeby religijne realizowali poza oficjalnymi kultami.

nach Telouch. Historische und archäologische Untersuchungen in Kommagene, hrsg. E. Winter, Bonn 2011, 217-245. W identyfikacji wielu świątyń Jowisza Dolicheńskiego, błędnie uznawanych za mitrea, ogromne znaczenie miały polsko-ukraińskie badania w Bałakławie: T. Sarnowski - O.Ja. Savelja, Balaklava. Römische Militärstation und Heiligtum des Iupiter Dolichenus, Światowit. Supplement Series A: Antiquity, vol. 5), Warszawa 2000.

${ }^{7}$ Kluczowe dla tego podejścia: R. MacMullen, The Legion as a Society, „Historia” 33 (1984) 440-456; The Roman Army as a Community: Including Papers of a Conference Held at Birkbeck College, University of London, on 11-12 January 1997, ed. A.K. Goldsworthy - I. Haynes, Portsmouth 1999. 


\section{WOJSKOWY KALENDARZ SAKRALNY}

1. Papirus Feriale Duranum i jego znaczenie. Próba interpretacji znaczenia społecznego uroczystości kultowych armii rzymskiej wymaga przynajmniej częściowej rekonstrukcji wojskowego kalendarza sakralnego. Specyfika zachowanych świadectw sprawia, że stosunkowo najlepiej poznanym pod tym względem okresem jest 1. poł. III wieku. Zdecydowanie najważniejszym źródłem pozwalającym na odtworzenie listy świąt obchodzonych przez armię rzymską jest tzw. Feriale Duranum, pochodzące z okresu panowania Aleksandra Sewera (1 X 208 - 13/21 III 235; cesarz od 18/19 III 222) ${ }^{8}$. Pod tą nazwą znany jest dokument papirusowy odnaleziony w Dura Europos. Zawiera on daty, przyporządkowane do nich okazje i rodzaj odpowiadających im ceremonii religijnych. Przyjęto nazywać go „kalendarzem sakralnym”, choć jego formie zdecydowanie lepiej odpowiada określenie „lista”. Uwzględnione są bowiem wyłącznie dni świąteczne, co wyraźnie różni ten dokument od większości znanych nam rzymskich kalendarzy, zawierających wszystkie dni roku, niezależnie od ich religijnego znaczenia. Treść dokumentu jednoznacznie wskazuje, że został on sporządzony w latach 222-235, na co wskazują odwołania do Aleksandra Sewera jako panującego władcy. Dokument można jednak datować dokładniej, ponieważ Julia Meza (ok. 170 - ok. 225) w momencie spisania listy już nie żyła, a jest określona jako ubóstwiona, diva, pamięci której poświęcone są publiczne modły (supplicatio) ${ }^{9}$. Wymieniony został także współrządzący cezar, z imion którego zachowało się wyłącznie jedno, „Luciu$\mathrm{s}^{\text {"10 }}$. Fakt, że za rządów Aleksandra Sewera mógł być to tylko Lucjusz Sejusz Herenniusz Salustiusz $(† 227)$, pozwala na precyzyjne zawężenie datowania do lat 225-22711. Ten teść Aleksandra Sewera został wyniesiony do godności cezara po małżeństwie córki, a w 227 r. doszło już do jego upadku i śmierci w wyniku nieudanej próby uzurpacji władzy cesarskiej.

Omawiany papirus odnaleziony został wewnątrz świątyni lokalnej bogini Azzanathkona, identyfikowanej z Artemida, przypuszczalnie powiązanej także z syryjską Atargatis $^{12}$. Dokument należał do przechowywanego w tej budowli archiwum oddziału Palmyreńczyków (cohors XX Palmyrenorum milliaria equitata), stacjonującego w Dura Europos aż do zniszczenia miasta przez Szapura I $(† 272)$ w roku 256. Na rzymskim Wschodzie wiele jednostek

${ }^{8}$ Por. R.O. Fink - A.S. Hooey - W.S. Snyder, The Feriale Duranum, „Yale Classical Studies” 7 (1940) 1-222; C.B. Welles - R.O. Fink - J.F. Gilliam, The Excavations at Dura-Europos, Final Report V, Part I: The Parchments and Papyri, New Haven 1959, no. 54; R.O. Fink, Roman Military Records on Papyrus, Cleveland 1971, no. 117; dostępne także on-line: http://papyri.info/ddbdp/rom. mil.rec;1;117 (dostęp: 8 listopada 2014).

${ }^{9}$ Por. Feriale Duranum II 7.

${ }^{10}$ Por. tamże I 11-12.

${ }^{11}$ Por. H.W. Benario, The Date of the „Feriale Duranum”, „Historia” 11 (1962) fasc. 2, 192-196.

${ }^{12}$ Por. N.J. Andrade, Syrian Identity in the Greco-Roman World, Cambridge 2013, 231-232. 
stacjonowało w obrębie miast, a korzystanie z cywilnych obiektów sakralnych przez administrację wojskową było stosunkowo często spotykane ${ }^{13}$. Użytkowanie tych samych budowli powodowało zacieśnienie stosunków między armią a lokalną ludnością, jednak - wobec ograniczenia dostępnej wewnątrz murów przestrzeni - miało przede wszystkim znaczenie praktyczne.

2. Uniwersalny charakter kalendarza. W kontekście rozważań nad społecznym znaczeniem oficjalnych wojskowych ceremonii szczególnie ważny jest fakt, że odnaleziony w Dura Europos kalendarz nie ma żadnych cech wskazujących na jego lokalny charakter ${ }^{14}$. Nie występują w nim święta typowe dla tego miasta, dla Syrii, ani nawet dla szeroko rozumianego rzymskiego Wschodu. Brak też ceremonii palmyreńskich, jakich można by się spodziewać po stacjonującym tam oddziale. Jest to tym bardziej uderzające, że na przykład świątynie wzniesione przez Palmyreńczyków ku czci bóstw z ich ojczyzny są znane z różnych rejonów cesarstwa, m.in. z Dacji ${ }^{15}$. Ta grupa ludności zachowywała zatem własne, charakterystyczne kulty pomimo przeniesienia do zupełnie innego regionu cesarstwa i do obcego środowiska kulturowego. Wskazuje to na uniwersalność dokumentu znanego jako Feriale Duranum. Nie tylko nie był on przeznaczony wyłącznie dla jednego oddziału, lecz należy widzieć w nim spis oficjalnych świąt obchodzonych przez całą armię rzymska, niezależnie od pochodzenia jednostek czy miejsca ich stacjonowania ${ }^{16}$. Poszczególne oddziały prawdopodobnie mogły odbywać także dodatkowe, półoficjalne uroczystości. Niewielka ilość źródeł nie pozwala na stwierdzenie, czy udział w nich zależał tylko od woli żołnierzy, czy był odgórnie narzucany przez dowództwo. Ścienne malowidło ze świątyni w Dura Europos wyraźnie wskazuje na udział wojskowych w tego rodzaju kultach ${ }^{17}$. Wśród nich znajduje się także dowódca oddziału, Juliusz Terencjusz, spełniający ofiarę. Prawdopodobnie tego rodzaju obrzędy stanowiły manifestację własnej tożsamości kulturowej i jako takie zapewne były ograniczone do tych spośród członków oddziału, którzy rzeczywiście byli pochodzenia etnicznego określonego w nazwie jednostki.

${ }^{13}$ Por. I.P. Haynes, Blood of the Provinces: the Roman Auxilia and the Making of Provincial Society from Augustus to the Severans, Oxford 2013, 150-152.

${ }^{14}$ Por. A.D. Nock, The Roman Army and the Roman Religious Year, HTR 40 (1952) 192-202; J. Helgeland, Roman Army Religion, ANRW II 16. 2, 1487.

${ }^{15}$ Por. A. Diaconescu, Temples of Ethnic Communities (Assembly Halls) in Roman Dacia. An Architectural Prospective, „Acta Musei Napocensis” 45-46 (2008-2009) 139.

${ }^{16}$ Por. Nock, The Roman Army and the Roman Religious Year; s. 202, Helgeland, Roman Army Religion, s. 1481; Birley, The Religion of Roman Army, s. 1510; D. Kossmann, Römische Soldaten als Teilnehmer von Festen, w: Festrituale in der römischen Kaiserzeit, hrsg. J. Rüpke, Tübingen 2008, 134-135.

${ }^{17}$ Por. L. Dirven, The Palmyrenes of Dura-Europos: A Study of Religious Interaction in Roman Syria, Leiden 1999, 186-188 i 304-307. 
Zachowana część Feriale Duranum obejmuje mniej więcej trzy pierwsze kwartały roku, od stycznia do września. Ze względu na luki w tekście niektóre jego partie zostały w publikacji zrekonstruowane w oparciu o inne źródła. Jednak dotyczyło to głównie początkowych fragmentów kolejnych linii tekstu, gdzie znajdowały się daty dzienne. Sprawia to, że ewentualne wątpliwości odnośnie do zaproponowanego przez wydawców tekstu mogą dotyczyć jedynie precyzyjnego umieszczenia niektórych świąt $\mathrm{w}$ obrębie danego miesiąca, ale nie ich kolejności, intencji i rodzaju składanych ofiar czy modłów ${ }^{18}$. Część zawierająca obchodzone okazje świąteczne oraz przypisane im ceremonie kultowe zachowała się $\mathrm{w}$ stosunkowo dobrym stanie, co w połączeniu z zastosowaniem powtarzających się, właściwie identycznie zredagowanych formuł pozwala na względnie wiarygodną rekonstrukcję 3/4 rocznego kalendarza sakralnego armii rzymskiej za Aleksandra Sewera. Wartość Feriale Duranum dla badań nad ceremoniami kultowymi armii rzymskiej nie ogranicza się jednak wyłącznie do rekonstrukcji sytuacji za panowania jednego władcy. Zebrane przez Duncana Fishwicka świadectwa inskrypcji wystawionych przez armię rzymską zawierających datę dzienną ich dedykacji ${ }^{19}$ potwierdzają dane zawarte w Feriale Duranum. Co ciekawe, poświadczony przez inskrypcje z datami dziennymi świąteczny charakter dni nie był ograniczony wyłącznie do przepisanych przez kalendarz ofiar czy publicznych modłów. Program ceremonii był uzupełniany o dodatkowe elementy lub intencje zgodnie $\mathrm{z}$ aktualnymi potrzebami kultowymi danego oddziału. Wiele z ołtarzy wystawionych w święta poświadczone w Feriale Duranum dedykowano bóstwom, których nie znajdujemy w odpowiednich pozycjach listy ofiar ${ }^{20}$.

3. Zarys rozwoju wojskowego kalendarza sakralnego. W przypadku dwóch pierwszych wieków cesarstwa nie dysponujemy niestety żadnym porównywalnym źródłem, co sprawia, że dla wojskowego kalendarza tych czasów możliwe są jedynie częściowe rekonstrukcje. Przede wszystkim tworzyć je można poprzez konfrontację zawartości Feriale Duranum z innymi źródłami. Analiza wewnętrznej struktury kalendarza pozwala na założenie, że lista oficjalnych świąt wojskowych obowiązywała już wcześniej, ale podlegała wielu aktualizacjom. Powstanie pierwotnej wersji takiego dokumentu ulokowano hipotetycznie za panowania Augusta (23 IX 63 prz. Chr. - 19 VIII 14 po Chr.; cesarz od 16 I 27 prz. Chr.) $)^{21}$. Doskonale pasuje to nie tylko do jego znaczenia

${ }^{18}$ Rekonstrukcja tekstu zaproponowana w pierwotnym wydaniu (Fink - Hooey - Snyder, The Feriale Duranum) po stosunkowo niewielu zmianach (Fink, Roman Military Records on Papyrus, no. 117) pozostaje do dziś aktualna.

${ }^{19}$ Por. D. Fishwick, Dated Inscriptions and the Feriale Duranum, „Syria” 65 (1988) fasc. 3-4, 349-361.

${ }^{20}$ Por. tamże, s. 353.

${ }^{21}$ Por. J.F. Gilliam, The Roman Military Feriale, HTR 47 (1954) 184; Fishwick, Dated Inscriptions and the Feriale Duranum, s. 349-350. 
jako reorganizatora armii rzymskiej i twórcy jej struktury z okresu pryncypatu, lecz także do aktywności na polu reformy kalendarza oraz roli odnowiciela rzymskiej religii ${ }^{22}$. Pozwala to na założenie, że w ogólnym zarysie sakralny kalendarz armii rzymskiej zachowywał swój kształt przynajmniej od przełomu er po 1. poł. III wieku. Niewielka liczba późniejszych źródeł nie pozwala odpowiedzieć na pytanie, czy podobnie kształtował się pogański kalendarz sakralny zniesiony w IV w., być może już przez Konstantyna Wielkiego (ok. 272 - 22 V 337; cesarz od 25 VII 306). Jest to jednak bardzo prawdopodobne.

4. Podział wojskowych ceremonii kultowych. Wśród uroczystości zawartych w liście Feriale Duranum przywykło się wyróżniać kilka głównych kategorii ${ }^{23}$. Po pierwsze są to stosunkowo nieliczne święta zaczerpnięte z kalendarza sakralnego oficjalnej religii rzymskiej, jak Neptunalia czy festiwal ku czci Westy ${ }^{24}$. Druga kategoria to ceremonie bezpośrednio związane z wojskiem: dzień dorocznego odnowienia przysięgi ${ }^{25}$ czy wypłaty żołdu i honorowego zwalniania weteranów ${ }^{26}$. Celebrowane były także rozmaite jubileusze związane $\mathrm{z}$ osobą panującego, $\mathrm{w}$ tym np. uzyskania przez niego poszczególnych godności i tytułów ${ }^{27}$. W ich trakcie bóstwom opiekuńczym składano ofiary $\mathrm{w}$ intencji bezpieczeństwa i powodzenia władcy. Najliczniejsza grupa ceremonii poświęcona była deifikowanym cesarzom i cesarzowym. Ofiary i publiczne modły upamiętniały dni ich urodzin bądź objęcia władzy. W Feriale Duranum najwięcej tego rodzaju kommemoracyjnych uroczystości poświęconych było Septymiuszowi Sewerowi (11 IV 145/146 - 4 II 211; cesarz od 9 IV 193), w tym także jego zwycięstwu nad Partami ${ }^{28}$. Aleksander Sewer podkreślał $\mathrm{w}$ ten sposób własne prawa do tronu i pokrewieństwo z władcą skutecznym i szczególnie popularnym wśród wojskowych. Szereg okazji trudno jednak jednoznacznie zaklasyfikować wedle tych tradycyjnych kryteriów. Wiele uroczystości łączyło bowiem elementy o różnej wymowie. Na przykład jedne z najsłabiej poznanych świąt, a mianowicie obchodzone dwukrotnie

${ }^{22}$ Dyskusyjna pozostaje kwestia, w jakim stopniu August był odnowicielem tradycyjnej religii rzymskiej. W jego działalności widać też wyraźne dążenie do uczynienia z kultu elementu jednoczącego państwo, co było źródłem wielu innowacji na tym polu, por. M. Jaczynowska, Une religion de la loyauté au début de l'Empire romain, „Dialogues d'Histoire Ancienne” 15 (1989) fasc. 2, 159178; także M. Jaczynowska, Religia lojalności w poczatkach cesarstwa rzymskiego, w: taż, Studia z dziejów antycznego Rzymu, Toruń 2003, 89-121.

${ }^{23}$ Por. Kossmann, Römische Soldaten als Teilnehmer von Festen, s. 135-136.

${ }^{24}$ Por. Feriale Duranum II 22 (Neptunalia); tamże II 15 (Vestalia).

${ }^{25}$ Por. tamże I 2-6.

${ }^{26}$ Por. tamże I 7-9.

${ }^{27} \mathrm{Na}$ temat miejsca zjawisk określanych terminem „kultu cesarskiego” w religii armii por. M. Ziółkowski, Kult cesarski w religii wojsk rzymskich w Brytanii (I-III w. n.e.), „Balcanica Posnaniensia: Acta et studia" 3 (1984) 167-176.

${ }^{28}$ Por Feriale Duranum I 14-17; II 3; II 4; II 10-11. 
rosaliae signorum ${ }^{29}$, musiało mieć wyraźny wojskowy charakter ${ }^{30}$. W nazwie pojawiają się bowiem znaki bojowe oddziałów, które tego dnia prawdopodobnie były wieńczone kwiatami ${ }^{31}$. Możliwy jest jednak także ich związek z obchodzonymi w zbliżonym momencie roku „cywilnymi” Rozaliami. Z kolei wielu stricte wojskowym ceremoniom towarzyszyły ofiary o pomyślność dla panującego. Należy w tym widzieć próbę zapewnienia sobie lojalności żołnierzy przez ewidentne podkreślenie asocjacji między osobą władcy a momentami realizacji przywilejów czy wypłacania żołdu oraz celebracjami szczególnie bliskimi duchowości wojskowych.

\section{ZNACZENIE WOJSKOWYCH CEREMONII RELIGIJNYCH DLA ARMII JAKO SPOŁECZNOŚCI}

Wydaje się, że przedstawiony powyżej tradycyjny podział ceremonii kultowych armii rzymskiej według ich intencji i wypełnianych rytuałów nie najlepiej opisuje ich społeczne znaczenie. Choć jest najzupełniej poprawny z punktu widzenia badań nad samym kultem i jego formami, nie przynosi niemal żadnych informacji na temat znaczenia, jakie uroczystości niosły dla samej społeczności wojskowych, czy również prób uzyskania wpływu na nastawienie żołnierzy za pomocą doboru celebrowanych okazji.

1. Wymowa uroczystości - lojalność i hierarchiczność. Zwracając uwagę przede wszystkim na wymowę ideową i propagandową ceremonii, podkreślić należy ogromną liczbę uroczystości związanych z lojalnością wobec państwa i władcy, obejmujących zarówno ofiary za pomyślność cesarza jak i ku czci jego deifikowanych poprzedników i ich małżonek. Warto jednak zauważyć, że bardzo wiele $\mathrm{z}$ nich zawiera $\mathrm{w}$ sobie drugi element, ściśle związany z samą społecznością wojskowych, gdyż we władcach widzieć należy także wodzów naczelnych oraz dobroczyńców armii ${ }^{32}$. Na świadome podkreślanie tej roli jednoznacznie wskazuje obecność w Feriale Duranum ceremonii poświęconej pamięci Germanika (24 V 15 prz. Chr. - 10 X 19 po Chr.) ${ }^{33}$. Jest to tym istotniejsze, że ów utalentowany i uwielbiany przez żołnierzy wódz nie został deifikowany, a zatem stanowi absolutny wyjątek w obrębie kalendarza sakralnego. Uroczystości, które promowały lojalność wobec państwa i władcy, były zarazem uwydatnieniem wyróżnionej pozycji armii w społeczeństwie, wynikającej

${ }^{29}$ Por. tamże II 8; II 14.

${ }^{30}$ Por. A.S. Hoey, Rosaliae signorum, HTR 30 (1937) 15-35.

${ }^{31}$ Rytuał ten najprawdopodobniej wyobrażono na reliefie odnalezionym w Corbridge, por. I.A. Richmond, Roman Legionaries at Corbridge, their supply-base, temples and religious cults, „Archaeologia Aeliana. 4th Series” 21 (1943) 163.

${ }^{32} \mathrm{O}$ pozycji wodzów w sferze religijnej por. M. Jaczynowska, Kult wodzów rzymskich w okresie Republiki, „Balcanica Posnaniensia: Acta et studia” 3 (1984) 157-165.

${ }^{33}$ Por. Feriale Duranum II 12-13. 
ze szczególnych relacji z panującym. Były one także istotne dla morale i spójności armii, gdyż wyrażały przywiązanie do hierarchii oraz ustalonego porządku społecznego, dwóch idei kluczowych dla funkcjonowania tej instytucji.

\section{Rola świadomości instytucjonalnej w kształtowaniu kalendarza sa-} kralnego. Znany z Feriale Duranum kalendarz sakralny sprawia wrażenie zaskakująco spójnego, jak na dokument powstający w wyniku trwającego ponad dwa wieki procesu modyfikacji i uzupełniania pierwotnej augustiańskiej listy. Nie należy chyba przeceniać chęci i możliwości władców w zakresie manipulowania postawami żołnierzy poprzez odgórnie narzucony kalendarz sakralny ${ }^{34}$. Skuteczność takiej próby byłaby wątpliwa ${ }^{35}$, gdyż lojalność żołnierzy zależała w zdecydowanie większym stopniu od innych czynników. Szczególnie Aleksander Sewer, pomny losu swego kuzyna Heliogabala (204 - 11 III 222, cesarz od 16 V 218), musiał być świadomy tego, że wpływ innowacji na polu kultu na nastawienie wojska był raczej ograniczony, jeśli nie wręcz negatywny. Liczne przykłady, w tym także Sewerów, wskazują jednak, że armia wykazywała skłonność do lojalności wobec swych dobroczyńców oraz ich krewnych niezależnie od kwestii religijnych. Wprost wynika to z dość typowego dla tego rodzaju instytucji konserwatyzmu oraz trwałości pamięci instytucjonalnej ${ }^{36}$. Wydaje się prawdopodobne, że stałość kalendarza sakralnego wynika właśnie $\mathrm{z}$ tych cech charakteryzujących społeczność żołnierzy i jej potrzeby religijne. Można dopatrywać się także kształtowania się specyficznej tożsamości, wyraźnie odróżniającej ich od cywilów i pozwalającej widzieć w nich do pewnego stopnia samoświadomą grupę społeczną. Skutkowało to czymś, co należy określić jako swego rodzaju potrzeby instytucjonalne. Armii musiało zależeć po pierwsze na promocji pewnych szczególnie dla niej ważnych wartości, a po drugie na zachowaniu ideowej ciąłości i kontynuacji. Można zatem sformułować tezę, że w zakresie społecznego znaczenia kultu armia rzymska wykazywała dość daleko posuniętą świadomość instytucjonalną. Dążono przy tym przede wszystkim do zachowania integralności wojska - postaw lojalnościowych i propaństwowych wśród żołnierzy, ale także utrzymania tradycji, umocnienia morale armii. Antropologia religii szczególnie akcentuje funkcję praktyk kultowych jako form wyrażania i utrwalania własnej tożsamości przez społeczności i grupy ${ }^{37}$.

\footnotetext{
${ }^{34}$ Por. Nock, The Roman Army and the Roman Religious Year, s. 203-229.

${ }^{35}$ Por. I.P. Haynes, The Romanisation of Religion in the ,Auxilia” of the Roman Imperial Army from Augustus to Septimus Severus, „Britannia” 24 (1993) 141-157.

${ }^{36}$ Por. tamże, s. 157.

${ }^{37}$ Por. C. Geertz, Religion as a Cultural System, w: Anthropological Approaches to the Study of Religion, ed. M. Banton, Edinburgh 1966, 1-46.
} 


\section{III. ŻOŁNIERZE WOBEC UROCZYSTOŚCI KULTOWYCH}

1. Zaangażowanie $\mathbf{w}$ oficjalne praktyki religijne. Rozważając znaczenie uroczystości kultowych nie sposób pominąc także ich roli w życiu duchowym poszczególnych żołnierzy. W tego rodzaju ceremoniach często widzi się przede wszystkim realizację potrzeby zapewnienia właściwych relacji społeczności z bogami, pax deorum ${ }^{38}$. Świadomość dopełnienia wymaganych rytuałów i ofiar w różny sposób musiała się przekładać na poszczególnych wojskowych, w zależności od ich światopoglądu i nastawienia do oficjalnego kultu. Możemy przypuszczać, że większy wpływ miała na tych żołnierzy, którym panteon wojskowy był bliższy, a zatem przede wszystkim na obywateli oraz mocniej zromanizowanych i przyzwyczajonych do postrzegania świata bogów w ramach religii państwowej, przez pryzmat interpretatio Romana. Trzeba pamiętać nie tylko o wielokrotnie podkreślanej skłonności wojskowych do przesądów, lecz także o autentycznej wierze we wpływ sił nadprzyrodzonych na los operacji wojennych i życie ich uczestników, przejawiający się chociażby najsłynniejszym, uwiecznionym na Kolumnie Marka Aureliusza i wzmiankowanym w wielu źródłach ,cudem deszczu”39. Także wynik procedury badania wnętrzności zwierząt ofiarnych mógł mieć ogromny wpływ na morale wojska przed bitwą ${ }^{40}$. Z tego względu właściwe spełnienie rytuałów mogło być źródłem komfortu religijnego i psychicznego, co ważne dla społeczności narażonej na ekstremalne zagrożenia i stres. $Z$ drugiej jednak strony, wojskowi przyzwyczajeni do innych form kultu oraz wzywania innych, charakterystycznych dla miejsc ich pochodzenia bóstw, zapewne postrzegali swój udział w oficjalnej religii przede wszystkim jako obowiązek, głębsze zaangażowanie rezerwując dla własnych, prywatnych praktyk.

2. Wpływ na tożsamość społeczną i kulturową żołnierzy. Wspólne uczestnictwo w kulcie stanowiło ważny czynnik jednoczący żołnierzy, którzy

${ }^{38}$ Zgodnie z koncepcją tzw. ,polis religion”, zakładającą rozdział między kultem publicznym a pobożnością prywatna, por. C. Sourvinou-Inwood, What is Polis Religion?, w: The Greek City from Homer to Alexander, ed. O. Murray - S. Price, Oxford 1990, 295-322; tenże, Further Aspects of Polis Religion, „Annali dell'Università degli Studi di Napoli «L'Orientale». Sezione Archeologia e Storia Antica" 10 (1988) 259-274. O rozwiniętej debacie na temat słuszności stosowania tego modelu w badaniach nad religią rzymską zob. zwłaszcza J. Rüpke, Kult jenseits der Polisreligion. Polemiken und Perspektiven, JbAC 47 (2004) 5-15.

39 „Cud deszczu”, por. P. Kovács, Marcus Aurelius' Rain Miracle and the Marcomannic Wars, Leiden 2009, 155-180; o wierze żołnierzy rzymskich we wpływ czynników nadprzyrodzonych na sukces działań wojennych, por. E.L. Wheeler, Shock and Awe: Battles of the Gods in Roman Imperial Warfare. Part I, w: L'Armée romaine et la religion sous le Haut-Empire romain: actes du quatrième congrès de Lyon (26-28 octobre 2006), éd. C. Wolff - Y. Le Bohec, Lyon 2009, 225-267.

${ }^{40}$ Por. E.L. Wheeler, Pullarii, Marsi, Haruspices, and Sacerdotes in the Roman Imperial Army, w: A Roman Miscellany. Essays in Honour of Anthony R. Birley on his Seventieth Birthday, ed. V.E. Hirschmann - A. Krieckhaus - H.M. Schellenberg, Gdańsk 2008, 189. 
przed wcieleniem do wojska mogli wywodzić się z bardzo odmiennych środowisk czy wręcz kręgów kulturowych. Nieprzypadkowo we wspólnym dla całej armii kalendarzu sakralnym dopatrywano się czynnika mającego duży wpływ na romanizację wojsk pomocniczych ${ }^{41}$. Choć współczesne interpretacje raczej sceptycznie odnoszą się do założenia, że było to w pełni świadomą polityką cesarzy, wieloletni udział żołnierzy w stricte rzymskich ceremoniach nie mógł pozostać bez wpływu na ich tożsamość kulturową i religijną ${ }^{42}$. W wojskowych uroczystościach można zatem widzieć pewne elementy edukacji obywatelskiej, przygotowującej żołnierzy wojsk pomocniczych do podjęcia po zakończeniu służby obowiązków religijnych weterana-obywatela ${ }^{43}$. Jednoczący charakter ceremonii kultowych w dużym stopniu polegał jednak po prostu na wspólnocie doświadczeń, i to zarówno na poziomie lokalnym, obejmującym współuczestniczących w wydarzeniu członków jednego oddziału, jak i w obrębie całego cesarstwa. W tym kontekście szczególnie ważna dla życia społecznego armii rzymskiej wydaje się masowość obowiązkowego udziału żołnierzy w uroczystościach religijnych. Niezależnie od typu jednostki i miejsca stacjonowania wszyscy rzymscy żołnierze w identyczny sposób obchodzili te same okazje. W ten sposób kształtowała się ich wspólna, ponadregionalna tożsamość. Ważnym jej elementem było to, że choć obchodzone przez armię uroczystości wpisywały się w tradycyjną religię rzymską, to dobór uroczystości i rozłożenie akcentów w obrębie roku sakralnego były szczególne i wyraźnie odrębne od kalendarzy cywilnych. Powszechność udziału miała dzięki temu niebagatelne znaczenie psychologiczne $-\mathrm{z}$ żołnierzy tworzyła osobną całość, grupę społeczną, zjednoczoną nie tylko przez posiadanie podobnego statusu czy identyczne zajęcie, ale także na fundamencie rytuału ${ }^{44}$. Nawet żołnierze, którzy własne potrzeby religijne realizowali głównie poza oficjalnym kultem wojskowym poprzez samą swą obecność w trakcie ceremonii stawali się częścią tej wspólnoty. Tego rodzaju jedność miała niebagatelne znaczenie dla kolektywnej tożsamości wojskowych, przekładającej się na morale żołnierzy i esprit de corps zarówno jednostki, jak i całej armii.

4. Święta jako dni wolne?. Znaczenie ceremonii religijnych w życiu żołnierzy w pewnym stopniu opierało się także na fakcie, że były one jedną z nielicznych okazji, które wiązały się z czasem wolnym. Jego ilość musiała kształtować się na zbliżonym poziomie właściwie przez cały okres istnienia Cesarstwa Rzymskiego. Według Hermiasza Sozomena (ok. 400 - ok. 450),

${ }^{41}$ Por. Nock, The Roman Army and the Roman Religious Year, s. 203-208.

${ }^{42}$ Por. Haynes, The Romanisation of Religion in the „Auxilia”, s. 157.

${ }^{43} \mathrm{O}$ aktywności religijnej weteranów por. K. Królczyk, Kulty religijne weteranów w Mezji Dolnej, w: Studia Moesiaca II, red. L. Mrozewicz - K. Ilski, Poznań 1994, 47-61.

${ }^{44} \mathrm{O}$ wpływie poszczególnych kategorii kultów typowych dla wojska na kształtowanie się grup por. J. Rüpke, Domi militiae: die religiöse Konstruktion des Krieges in Rom, Stuttgart 1990, 178-196. 
Konstantyn Wielki wprowadził w armii niedzielę jako święto ${ }^{45}$. Choć nie wiadomo, czy za panowania chrześcijańskich władców armia nie obchodziła także niektórych ważniejszych świąt, jeden dzień wolny w tygodniu niemal dokładnie odpowiada stosunkowi wynikającemu z zapisów Feriale Duranum. W zachowanej czesści tego kalendarza jedna ceremonia przypada bowiem na nieco mniej niż siedem dni. Taka ilość wolnego czasu wydaje się odpowiednia dla instytucji, która dążyła do zapewnienia swym członkom zajęcia i ze względów porządkowych nie mogła ich pozostawiać bezczynnymi, ponieważ to często bywało zgubne dla dyscypliny wojskowej ${ }^{46}$. Z drugiej strony, także pewien odpoczynek od tych często stosunkowo ciężkich obowiązków był niezbędny, by utrzymać armię w ryzach. Znane są przypadki, że rzymscy żołnierze buntowali się, gdy przyszło im wypełniać szczególnie żmudne zadania. Żywot cesarza Probusa (232-282; cesarz od 276) zawiera informację o tym, że wykorzystanie wojska do prac polowych spowodowało ich rebelię i śmierć władcy ${ }^{47}$. Przekaz ten jest doskonałym przykładem na to, jak sami starożytni postrzegali kwestię zachowania odpowiedniego balansu pomiędzy obowiązkami oraz czasem wolnym jako kluczową dla morale żołnierzy.

a) Obowiązek udziału w uroczystościach oraz towarzyszące im przeglądy i apele. W tym przypadku bardzo ważne jest jednak także i to, z jaką dokładnie ilością wolnego czasu wiązały się ceremonie religijne obchodzone przez oddział ${ }^{48}$. Dni świąteczne obejmowały bowiem także obowiązki, co sprawiało, że choć żołnierze mieli dzień cześsiowo wolny, to znajdowali się pod pewną kontrolą dowództwa. Po pierwsze, sama obecność w trakcie uroczystości była zapewne obligatoryjna. Oprócz ofiary i modłów przypuszczalnie była to także okazja do dokonania przeglądu oddziału, co mogło niekiedy przybierać również formę uroczystej, świątecznej parady ${ }^{49}$. Obecność większości żołnierzy służących w jednostce w jednym miejscu musiała być także okazją do odbywania apeli, wygłaszania przemówień przez dowódców czy odczytywania rozporządzeń i rozkazów. W budynkach komendantury wielu fortów i obozów rzymskich nieopodal świątyni sztandarów (aedes principiorum), centrum religijnego życia oddziału, znajdowały się murowane trybuny, które podczas tego rodzaju zgromadzeń wykorzystywane były

${ }^{45}$ Por. Sozomenus, HE I 8, 11-12, ed. J. Bidez, GCS 50, Berlin 1960, 19, 9-14, thum. S. Kazikowski: Hermiasz Sozomen, Historia Kościoła, Warszawa 1980, 47.

${ }^{46}$ Bogaty wybór wzmianek w źródłach, por. S.E. Phang, Roman Military Service: Ideologies of Discipline in the Late Republic and Early Principate, Cambridge 2008, 201-248. Niektóre wnioski autorki na temat roli pracy fizycznej w utrzymywaniu dyscypliny wydają się jednak posunięte zbyt daleko, jak choćby przyrównanie społecznego znaczenia relacji dowódca - żołnierze do stosunków panujących między właścicielem a niewolnikami.

${ }^{47}$ Por. Flavius Vopiscus, Probus XX 2-3, ed. w: The Scriptores Historia Augusta, with an English translation by D. Magie, vol. 3, LCL 263, Cambridge (Massachusetts) - London 1961, 376.

${ }^{48}$ Por. Rüpke, Domi militiae, s. 178-179.

${ }^{49}$ Por. Kossmann, Römische Soldaten als Teilnehmer von Festen, s. 146. 
jako mównice. Podobne platformy znajdowały się także na placach ćwiczeń, które służyły nie tylko jako miejsca treningu wojskowego, lecz również do odbywania masowych ceremonii. Inskrypcja z placu ćwiczeń w Lambaesis zawiera przemówienie Hadriana (14 I 76 - 10 VII 138; cesarz od 11 VIII 117) do żołnierzy, doskonale ilustrując związki zachodzące pomiędzy ćwiczeniami, pokazami i apelami wojskowymi, a uroczystościami religijnymi ${ }^{50}$. Platformy $\mathrm{w}$ tego rodzaju obiektach bywały wybudowane z kamienia lub usypane z ziemi, jednak możemy przypuszczać, że częściej wykorzystywano tymczasowe konstrukcje z drewna. Tego rodzaju urządzenia mogły nie pozostawić żadnych uchwytnych archeologicznie śladów. Świadectwa ich wykorzystywania można za to dopatrywać się na monetach. W scenach adlocutio, przemówień wygłaszanych do żołnierzy, postacie cesarzy i towarzyszących im niekiedy prefektów pretorian znajdują się na podiach dwóch typów. Pierwszy to prosta, prostopadłościenna platforma, prawdopodobnie ukazująca w uproszczony sposób konstrukcję murowaną ${ }^{51}$. Drugi musi być odpowiednikiem konstrukcji drewnianej, gdyż posiada wyraźnie wyróżnione nogi ${ }^{52}$. Także wały otaczające większość placów ćwiczeń mogły służyć do zapewnienia lepszej widoczności i akustyki zarówno w trakcie wojskowych ceremonii religijnych, jak i apeli.

b) Obowiązki ograniczające udzial w ceremoniach. Warto podkreślić, że masowość ceremonii religijnych nigdy nie przekładała się na zwolnienie wszystkich żołnierzy z ich obowiązkó $w^{53}$. Wspomnieć należy przede wszystkim o strażach w samym obozie, jak również o służbie patrolowej czy policyjnej, które musiały być wykonywane niezależnie od charakteru dnia ${ }^{54}$. Choć nie znamy dokładnej liczby wojskowych, którzy spełniali tego rodzaju obowiązki, musiała ona być znaczna. Wedle kalkulacji opartych na niezbyt jasnej treści De munitionibus castrorum, w obozach marszowych takie zadania wypełniała prawdopodobnie jedna piąta żołnierzy ${ }^{55}$. Ze względu na podział doby na cztery warty oznacza to, że w danym momencie co najmniej $1 / 20$ stanu osobowego danego zgrupowania była wyłączona z wszelkich innych aktywności. W obozach stałych sytuacja musiała wyglądać podobnie. Możemy przypuszczać, że ilość dni wolnych przysługujących żołnierzom była wyrównywana chociażby poprzez zwiększenie liczby przepustek w dni nieświąteczne. Zwyczaj ich przyznawania jest poświadczony m.in. przez papirusowe dokumenty

\footnotetext{
${ }^{50}$ Por. B. Rankov, Hadrian's Speeches in Africa: Exercises in the campus and Military Ideology, „Journal of Roman Archaeology” 18 (2005) fasc. 2, 650-654.

${ }^{51} \mathrm{Na}$ przykład sesterc Kaliguli, por. The Roman Imperial Coinage, vol. 1: Augustus to Vitellius, ed. by H. Mattingly - E.A. Sydenham, London 1923, no. 32.

${ }^{52}$ Na przykład sesterc Galby, por. The Roman Imperial Coinage, vol. 1, no. 464.

${ }^{53}$ Por. Kossmann, Römische Soldaten als Teilnehmer von Festen, s. 147.

${ }^{54}$ Por. Gilliam, The Roman Military Feriale, s. 187.

${ }_{55}$ Por. Pseudo-Hyginus, De munitionibus castrorum (De metatione castrorum), [wyd. łacińsko-polskie], tłum. I.A. Łuć - K. Królczyk, Pseudo-Hyginus, O wytyczaniu obozów wojskowych, Poznań 2010.
} 
i prywatne listy ${ }^{56}$. Dla dużej liczby żołnierzy święto oznaczało jednak zwolnienie od pracy, gdyż wojsko nie wykonywało wówczas najbardziej męczących prac, takich jak chociażby budowy czy rozmaite procesy produkcyjne. Choć zatem nawet $\mathrm{w}$ święta istniały pewne obowiązki do wypełnienia, to były one stosunkowo lekkie, a żołnierze odpoczywali przy okazji ceremonii religijnych od najcięższego wysiłku fizycznego oraz dysponowali znaczną ilością czasu wolnego. Ważne było także to, że większość żołnierzy dysponowała czasem wolnym w tym samym momencie, co wpływało na ich dalszą integrację. Istnienie pomiędzy członkami oddziału więzi koleżeńskich dodatnio wpływało zarówno na codzienne funkcjonowanie jednostki wojskowej, jak i na jej zwartość i morale w trakcie działań bojowych.

$* * *$

Podsumowując powyższe rozważania należy zauważyć, że oficjalne ceremonie religijne armii rzymskiej niosły szereg istotnych implikacji dla jej funkcjonowania nie tylko jako organizacji, ale także jako niezwykle specyficznej społeczności. Zdecydowanie wykraczały one poza znaczenia stricte religijne, jak zapewnienie żołnierzom duchowego komfortu wynikającego z realizacji niezbędnych ofiar. Mogły wpływać zarówno na motywację żołnierzy oraz ich nastawienie wobec państwa i władcy, jak i na kształtowanie się morale jednostki. Udział w ściśle określonych ceremoniach stawał się także podstawą formowania się poszczególnych oddziałów oraz całej armii jako grup społecznych. Nie można także zapomnieć, że ze względu na czas wolny towarzyszący tego rodzaju okazjom, stanowiły one niezwykle ważny przerywnik w jakże monotonnym codziennym życiu skoszarowanych żołnierzy. Dla wielu wojskowych, szczególnie tych, dla których oficjalna rzymska religia nie była bliska własnym potrzebom duchowym, mógł to być wręcz najważniejszy aspekt uroczystości kultowych armii rzymskiej.

\section{THE SOCIAL IMPORTANCE OF CULT CEREMONIES FOR THE ROMAN MILITARY DURING THE PRINCIPATE IN THE LIGHT OF FERIALE DURANUM}

\section{(Summary)}

The aim of the present paper is to thoroughly reconstruct the meaning of the official cult ceremonies for the social life of the Roman Imperial army. Crucial to the analysis is the evidence produced by the Feriale Duranum, a papyrus document dating to the reign of Severus Alexander, but supported also by other sourc-

\footnotetext{
${ }^{56}$ Por. P. Southerm, The Roman Army: a Social and Institutional History, Oxford 2007, 149.
} 
es. The matter of loyalty to the state and ruler is characteristic of most military ceremonies. Hierarchy and social order are emphasised as well, all four being values important for the military ideology. Participation in the same rites influenced the morale and esprit de corps not only in a particular unit, but also within the whole army. Therefore one can view the rites as an expression of a military identity, serving also to distinguish the soldiers as a separate social group. The official holidays were also of importance for the private life of a soldier, being one of few occasions when exemption from work and free time were granted. This made such ceremonies a welcome break from camp routine. As such, the official military religious rites were vital for the social life of both individual soldiers and military communities, be it units or even the whole army.

Key words: Roman army, military religion, sacral calendar, holidays, social groups.

Słowa kluczowe: armia rzymska, religia wojskowa, kalendarz sakralny, święta, czas wolny, grupy społeczne. 